\title{
新潟県中越沖地震における 災害廃棄物対策の評価
}

\section{EVALUATION OF DISPOSED DISASTER WASTE IN CASE OF THE NIIGATAKEN CHUETSU-OKI EARTHQUAKE IN 2007}

\author{
坂井 優美 ${ }^{1}$-木村 智博 ${ }^{2} \cdot$ 福田 誠 $^{3}$ ・橋本 治 ${ }^{4}$. \\ 岡田 勝也 ${ }^{5} \cdot$ 伊藤 真理 $^{6} \cdot$ 川原 潮子 ${ }^{7} \cdot$ 岩波 基 $^{8}$ \\ 1 元 新潟大学工学部 学部生 \\ ${ }^{2}$ 博士（環境学） 元 東京大学大学院生 (E-mail : mucunzhibo@yahoo.co.jp) \\ ${ }^{3}$ 工博 長岡工業高等専門学校 名誉教授（E-mail : fukudam@clock.ocn.ne.jp） \\ ${ }^{4}$ (財) 東京都環境整備公社 京浜島処理センター所長 \\ ${ }^{5}$ 工博 国士舘大学理工学部 教授 \\ ${ }^{6}$ 朝日新聞 記者 \\ 7 朝日新聞 記者 \\ ${ }^{8}$ 工博＼cjkstart長岡工業高等専門学校 准教授（E-mail：miwanami@nagaoka-ct.ac.jp）
}

\begin{abstract}
兵庫県南部地震以降, 廃萧物学会を中心に, 地盤工学領域では応用地質学会や日本粘土学会等が災害廃 棄物の調查を行うようになった. 本研究では 2007 年新潟県中越沖地震を例に, 廃棄物行政の実態を俯㒈し, 住民に求められる危機管理の方向性を現地調査やアンケート等で明らかにした。また, 東京都等の震災廃 棄物対策を参照しつつ, 地盤材としての有効性を検討した。この一連の流れで, 徹底した分別回収がなさ れたこと, 家族や住民間の協力で非常時の自主防災の成否につながったこと, 膨大な廃棄物でも適正処理 により環境影響を低減出来る可能性が筆者らの調查で示唆された。さうに廃棄物に内在する重金属にも言 及し，新潟県内海岸部での調査結果や処理技術の現状も参考のために概観した。
\end{abstract}

キーワード : 2007 年新潟県中越沖地震, 災害廃棄物問題, アンケート調査, 環境影響, 廃棄物 管理

\section{1. はじめに}

TIME 誌では早くから，アジア諸国等で深刻化する有 害廃棄物問題を特集してきた ${ }^{1)}$. 福林らはパプアニュー ギニアで住民による土囊利用の道路整備手法を扱い ${ }^{2)}$, 技術者の責務を論述している。 こうした廃棄物の有効利 用や分別回収に係る啓発を踏まえ, 筆者らは 2007 年新潟 県中越沖地震を例に，災害廃裹物の実態に基づいた軽減 策を，主に現地調查とアンケートから検討した。

我々は新潟県内で発生した地震に際し廃㶳物集積所を 調査し, 2004 年新潟県中越地震後の屋外の廃棄物仮置場 での異臭 $\left(\mathrm{NH}_{3} \cdot \mathrm{H}_{2} \mathrm{~S}\right.$ 等）を重視し， 2007 年新潟県中越 沖地震後の環境影響が一層, 危惧されると判断した. 本 稿では地震直後から 2008 年 2 月にかけ, 行政対応と集積 所管理業務の把握に努め，廃棄物対策を考察する.

なお，一般廃棄物は自治体，産業廃棄物は排出した事 業者が責任を持って処理することになっているが，災害 時には, 解体廃棄物を含む建築廃材と家財道具が大量に 発生し, これ等の廃棄物は災害廃棄物と定義されている.
1995年 1 月 17 日の兵庫県南部地震では約 2,000 万トン, 平年の一般廃棄物排出量の 8 倍相当に達し, 中には野焼 き等の不適切な処理が見られたことから，1998 年 10 月 に「震災廃棄物対策指針」や 2005 年 6 月の「水害廃棄物 対策指針」が施行され，国と自治体は防災計画の中で, 災害廃棄物処理処分計画とそれ等の実施体制を準備する ことに至った ${ }^{3)}$. 災害廃棄物対応は被災自治体の責任で 行われることとなり, 費用面では、災害廃棄物の処理処 分事業, 及び損傷した廃棄物処理処分施設の復旧に要す る費用の 2 分の 1 が国庫から補助される.

2004 年新潟県中越地震では旧山古志村が河道閉塞と なり，積雪期に入っても復旧に追われた. 積雪期の作業 は屋根雪処理中の人身事故等 ${ }^{4)}, 2004$ 年新潟県中越地震 では除雪を含む片付け作業に起因する地震関連死が顕在 化した. また, 復興に向け, 堆積土砂の放射線遮蔽材一 の転用の検討が行われた ${ }^{5}$ が，撤去作業において高齢者 層ではボランティアへの期待が高まった ${ }^{6 \sim 9)}$.

国土交通省北陸地方整備局湯沢砂防事務所は 2007 年 12 月 24 日, 新潟県長岡市山古志地区に東竹沢砂防堰堤 
を完成, 芋川を転流させた. 同箇所は 2004 年新潟県中越 地震で幅 $295 \mathrm{~m}$ ，奥行き $350 \mathrm{~m}$ にわたり約 130 万 $\mathrm{m}^{3}$ の土 砂が崩壊し, 処理が困難となった.

一方, 2007 年新潟県中越沖地震では瓦啋処理が優先さ れ，これは建物被害で住家被害が約 6 割，そのうち一部 損壊が約 8 割である等, 衛生面と道路網の確保が至上命 題となったことによる. 7.13 水害では発災後 1 ケ月の段 階で, 三条市の年間廃棄物量 4 万トンを超える 4 万 8 千 トンが市中心部に位置する競馬場近隣に集積され, 蚊や 蜾, 蚋, 虬の飛翔等, 廃棄物減量化が課題となった ${ }^{10)}$.

2000 年 10 月 6 日の鳥取県西部地震（M7.3）で塩ビ業 界が米子市・境港市に協力し, 廃プラスチックを再生管 の原材料に，一部はセメント原燃料として利用した ${ }^{11)}$.

\section{2. 災害廃棄物に係る現地調査}

\section{1. クリーンセンターかしわざきの被害と影響}

Figure 1 の柏崎市橋場地区に 1992 年に稼動した 1 日 処理能100トン,粗大ごみ 40 トンの可燃ごみ処理施設「ク リーンセンターかしわざき」は，高さ $59 \mathrm{~m} の \mathrm{RC}$ 製煙突 が地上 $18 \mathrm{~m}$ 付近で折損し, $6 \mathrm{~m}$ 沈降傾斜した. 同市と刈 羽村のごみ焼却処理が不能となり, 新潟県内自治体に協 力を要請(地震当日から 10 月末まで市内で 1 万 1 千トン 回収）し，処理が急がれる粗大ごみ等は JR 貨物のクリ ーンかわさき号（川崎市の生活廃棄物輸送コンテナ）を 使用, トラックと比較し $\mathrm{CO}_{2} \cdot \mathrm{NO}_{\mathrm{X}}$ が $90 \%$ 以上もの削減 が可能となった. 柏崎市で処理困難な廃棄物を 2007 年 9 月〜 10 月上旬に 1 日当たり 1〜2 トンを川崎市で受け入 れ, 輸送経路は南長岡駅から川崎貨物駅経由で浮島, 数 十トンが処理された. なお, Table 1 は復興期までの各 自治体の取り扱いを示したが，川崎市の対応は緊急的で あるため，本文中での言及にとどめた.

煙突の復旧は, 破損した外筒及び煙突の倒壊防止工事 に着手し，9 月 5 日からの解体作業による煙突撤去後, 高さ 35m の仮設煙突を設置した (Photograph 1〜 Photograph 3). 処理工場棟内の被害では, (1)給塵機の ロッドの湾曲, (2)焼却炉内の耐火物の滑落, (3)各送風機 の芯のずれ，(4)ダクトのずれ，(5)各設備の架台のずれ，

(6)約 15 トンの河川水路過塔のずれ, 等が確認され, 仮設 煙突設置までの期間と並行し，施設内を修繥した。

同センターは 2007 年 11 月 15 日に再開し, 仮煙突の高 さ $35 \mathrm{~m}$, 市担当者によれば, 2008 年度以降に 3 億 5 千万 円をかけ修繥される.この他に,「エコグリーン柏崎夏渡」, 柏崎市宝町のコマツ跡地（仮置場）でも影響が生じ 12), 現在も下水道工事に係る副産物処理が懸案となっている.

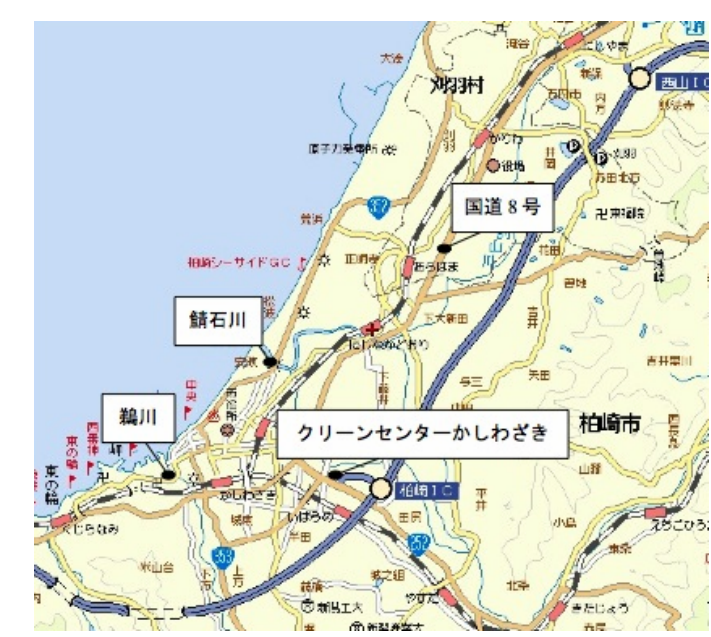

Figure 1 クリーンセンターかしわざきの位置

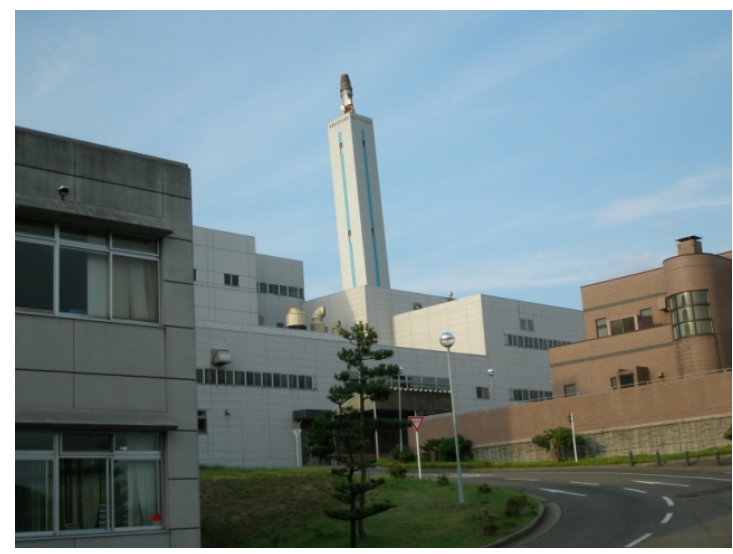

Photograph 1 クリーンセンターかしわざきの被災状況 (2007 年 7 月 19 日撮影)

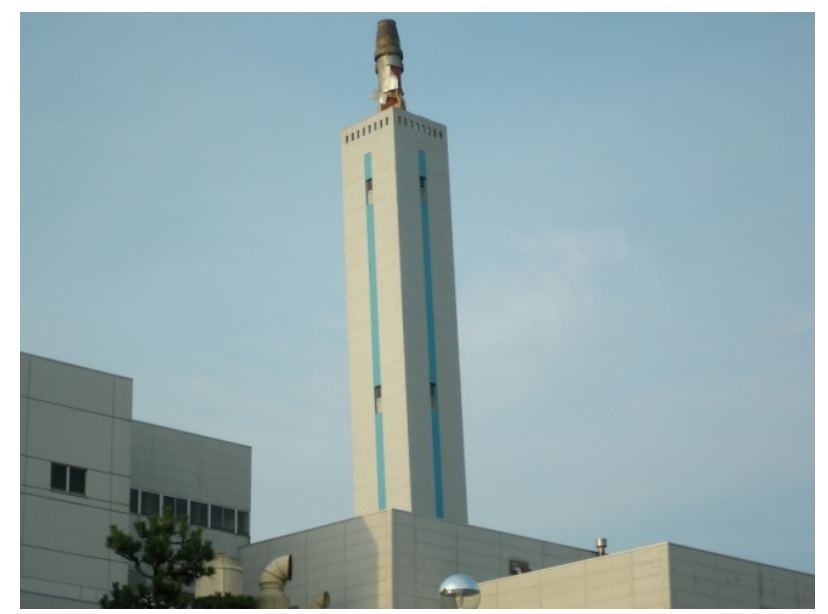

Photograph 2 RC 製煙突破損（2007 年 7 月 19 日撮影） 
Table 1 柏崎市の処理依頼に基づく各自治体の搬入総量（家庭ごみ収集記録を計算）

\begin{tabular}{|c|c|c|c|c|c|c|c|}
\hline \multicolumn{2}{|c|}{ 自治体 } & 7月 & 8 月 & 9月 & 10月 & 11月 & 合計 $(\mathrm{kg})$ \\
\hline \multirow{14}{*}{ 県内 } & 新潟市 & 578,570 & $1,009,790$ & $1,121,260$ & $1,303,230$ & 426,320 & $4,439,170$ \\
\hline & 長岡市 & 139,600 & 34,920 & 228,090 & 256,120 & 107,010 & 765,740 \\
\hline & 三条市 & 33,000 & 138,490 & 133,360 & 151,320 & 15,560 & 471,730 \\
\hline & 見附市 & 24,300 & 94,850 & 60,420 & 34,050 & 0 & 213,620 \\
\hline & 采魝市 & 42,235 & 7,780 & 0 & 0 & 0 & 50,015 \\
\hline & 魚沼市 & 60,370 & 80,210 & 35,970 & 0 & 53,330 & 229,880 \\
\hline & 南魚沼市 & 79,270 & 203,220 & 33,910 & 103,610 & 0 & 420,010 \\
\hline & 上越市 & 30,390 & 356,170 & 8,890 & 0 & 0 & 395,450 \\
\hline & 十日町市 & 54,760 & 131,760 & 202,250 & 33,620 & 0 & 422,390 \\
\hline & 小千谷市 & 0 & 795,305 & 886,030 & 299,485 & 0 & $1,980,820$ \\
\hline & 燕·弥彦 & 54,590 & 86,170 & 89,820 & 0 & 0 & 230,580 \\
\hline & 五泉地域 & 17,470 & 63,260 & 30,370 & 8,010 & 0 & 119,110 \\
\hline & 加茂 $\cdot$ 田上 & 0 & 79,090 & 72,560 & 81,410 & 2,700 & 235,760 \\
\hline & 新井頸南 & 0 & 0 & 0 & 85,520 & 0 & 85,520 \\
\hline \multirow{4}{*}{ 県外 } & 福島県 & 3,180 & 7,850 & 0 & 0 & 0 & 11,030 \\
\hline & 富山市 & 55,800 & 12,600 & 0 & 0 & 0 & 68,400 \\
\hline & 宇都宮市 & 0 & 73,740 & 0 & 0 & 0 & 73,740 \\
\hline & 福井市 & 0 & 11,470 & 0 & 9,010 & 0 & 20,480 \\
\hline \multicolumn{2}{|c|}{ 合計 $(\mathrm{kg})$} & 1,173,535 & 3,186,675 & 2,902,930 & $2,365,385$ & 604,920 & $10,233,445$ \\
\hline
\end{tabular}

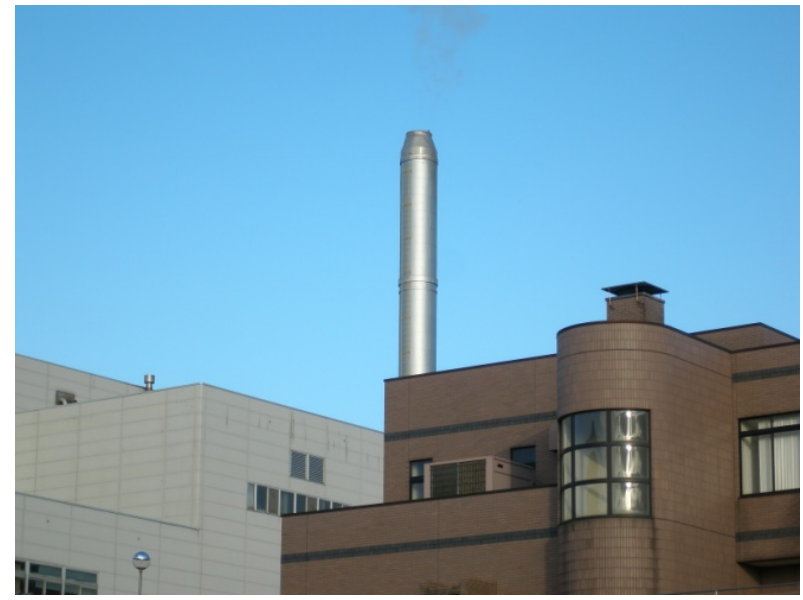

Photograph 3 仮設煙突敷設（2007 年 11 月 28 日撮影）

\section{（1）焼却施設被災後の柏崎市での影響}

柏崎市の家庭ごみは, 通常1日 80〜120 トン発生する.

7 月 17 日から通常収集（週 3 回）を行ったものの，同月 19 日に「クリーンセンターかしわざき」のピット内が満 杯状態の約 1,000 トンに達した. そのため, 柏崎市夏渡 にある最終処分場に仮置きしつつ， 7 月 19 日〜11月 12 日にわたり県内・県外の他自治体に可燃ごみの処理を依 頼した. 他自治体一搬出した総量は, 平成 16 年度の柏崎 市可燃ごみ処理量の約 4倍に相当する10,233 トンとなり， 中でも約 4 割の可燃ごみが新潟市一搬出された。 また, 小千谷市，長岡市が可燃ごみを受け入れ，近隣市町村の 応援が目立った. その後, 同施設が仮復旧し, 2007 年 11 月 15 日以降は通常の受け入れ態勢に移行出来た.

\section{（2）焼却施設被災後の刚羽村での影響}

刈羽村の家庭ごみは 1 日約 4 トン発生し, 可燃ごみは 全て「クリーンセンターかしわざき」で処理されるが, 道路被害から搬出不能に陥り, 震災後 2 週間でごみ量が ピークに達した. 増大寸る住民の苦情を受け，7月 18 日 〜11月 24 日に長岡市へ全ての可燃ごみ処理を依頼した. 同市一の搬出総量は, 平成 16 年度刈羽村の可燃ごみ処理 量の半分相当の 603 トンであった (Figure 2).

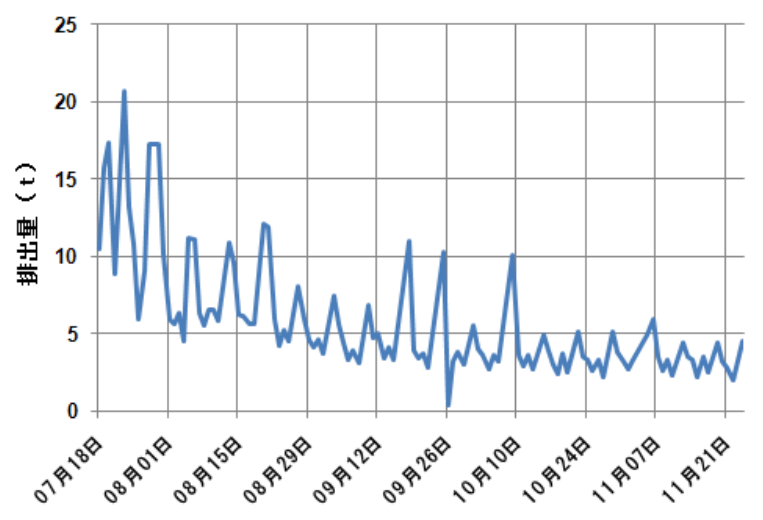

Figure 2 刈羽村から長岡市へのごみ搬出量の推移

\section{2. 柏崎市での現地調查結果}

\section{（1）柏崎市内の家財廃棄物収集 - 処理}

柏崎市が対応する家庭ごみ焼却とは別に，資源ごみは 市内 12 地区に分け 9 月 10 日〜28 日の 1 回のみの特別収 集日を設定した。 また，ごみ撤去の緊急性が高い箇所に 
限り, 月・水・金に柏崎市と委託業者によって収集が行 われた. 収集された資源ごみは不燃ごみ・粗大ごみと同 様, 柏崎市宝町の市有地の工場跡地に集積, 一時仮置き された後，業者一搬出された (Photograph 4).

不燃ごみ（主にペットボトル）は地区別に，月２回の 収集を, 粗大ごみは有料で個別収集を行っている. 地震 後, 不燃ごみ・粗大ごみの対応として, 1 つの地区を 2 日連続で収集した. 1 日目は「不燃ごみ・家電・布団・ 絨緞類」, 2 日目は「布団・絨緞以外の粗大ごみ」という 分別で, 午前 6 時〜8 時に収集を行った. 排出場所は緊 急措置的に, 各町内の可燃ごみの集積場所（ゴミステー ション）である. 収集車両は新潟県内の民間 2 団体を中 軸として, 73 業者, 延べ 803 台と, 柏崎市と柏崎市の委 託業者の十数台が充当された.

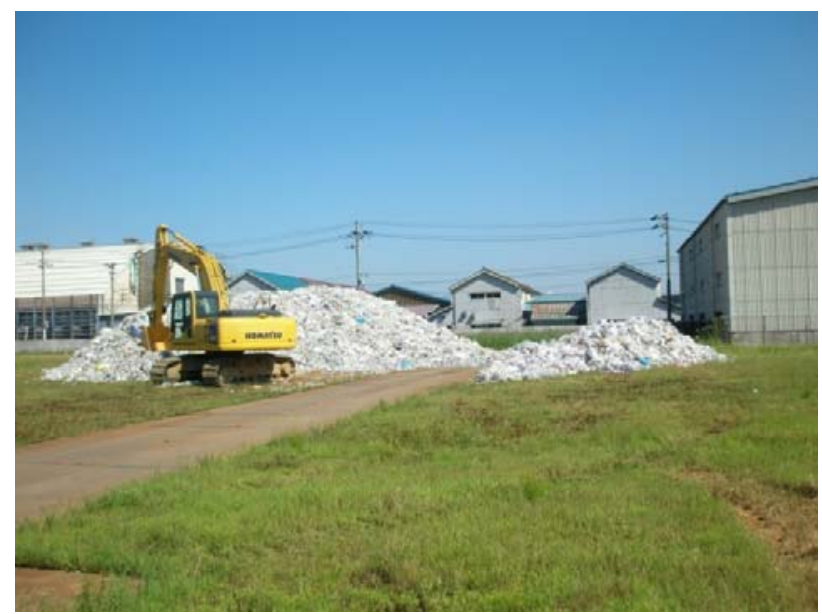

Photograph 4 空き缶をバックホウで運搬 - 処理後に資 源化（柏崎市宝町で地震直後から稼動）

収集したごみは, 柏崎市宝町の 6ha の市有地に, 大き $<5$ 種類に分別集積された. 分別集積された不然・粗大 ごみは，全て民間廃棄物処理業者に委託した。

(1)不燃ごみ（食器・ガラスの破片）

(2)不燃性粗大ごみ（自転車・マットレス）

(3)可燃性粗大ごみ (䈍䇺・テーブル・椅子)

(4)家電 4 品目（テレビ・冷蔵冷凍庫・エアコン・洗濯機）

(5)その他家電 (パソコン・その他家電製品)

ただ，住民は集積所の悪臭に対する不満は大きかった が, Photograph 5 に示したのとは裏腹に, マットレスや ウレタン放置には無関心であった. しかしながら, 発火 によるシアン化水素（青酸ガス）の発生が懸念される.

また, 柏崎市の家財廃棄物処理処分計画では, 不燃ご み, 不燃性粗大ごみ, 可燃性粗大ごみ, 廃家電 4 品目に 分けられた.これ等は全て, 収集後に集積

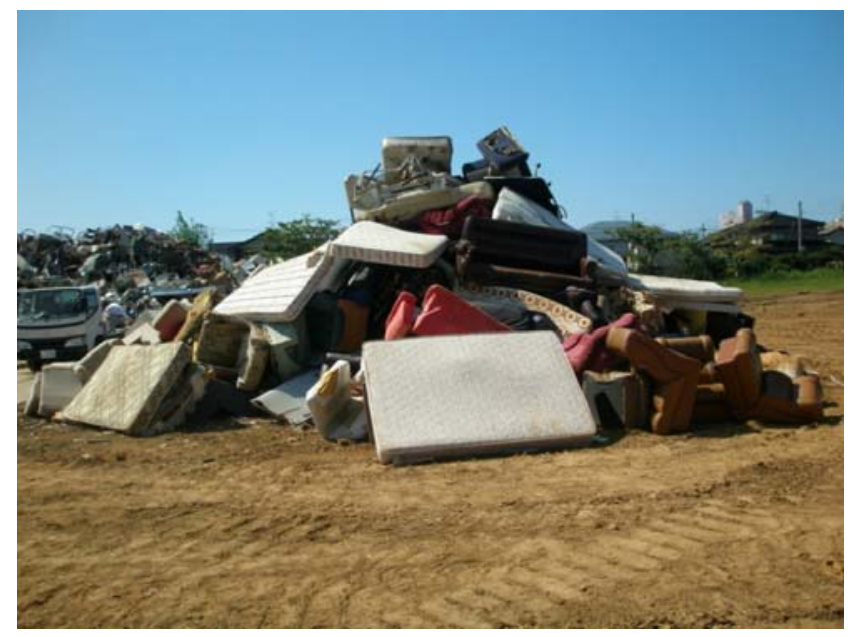

Photograph 5 宝町で不燃ごみ（自転車, マットレス）

所に搬入され，(1)不然性粗大ごみは金属回収後に破砕処 理，残渣は埋立処分となり，(2)可燃性粗大ごみは破砕処 理後, 燃料として資源化される. なお，埋立処分される 廃棄物は県内 1 ヶ所の第 3 セクタ一処分場（出雲崎町） と県外 2 ヶ所の民間処分場（長野県・山形県）で埋め立 てられた.

\section{（2）柏崎市内の解体廃棄物（建築廃材）収集 - 処理}

2007 年 8 月 5 日から被災住宅を解体寸る業者の指定登 録受付を開始し, 同 6 日から指定登録解体業者による被 災住宅等の解体処理に着手した. 原則, 解体家屋は同現 場で分別され集積所，若しくは処理施設に搬入された. ただ，管理票がある場合のみ混載を認めた．柏崎市鯨波 のクレ一射撃場の集積所で 8 月 6 日〜 10月 6 日に, 2007 年10月 15 日〜2008年1月 30 日に家財廃棄物とともに, 柏崎市宝町の工場跡地に搬入された. 同2月 4 日からは, 安政町にある柏崎市下水処理施設の空き地に解体残渣を 仮置きし，現在に至っている. 鯨波の集積所が閉鎖され た理由は, 宝町の 6ha を有する集積所と比較して手狭と なったこと, 各種廃棄物の一元管理の必要性が高まった ことによる. 損傷家屋等の処分で解体・修繥費は自己負 担ながら, 収集・運搬・処分費は全額市が負担した. 但 し, 後述寸る住民アンケートの結果や, 2007 年 8 月に実 施した柏崎市住民へのヒアリングから, 自主的に処分場 まで運搬した例も散見され, 着の身着のままで片付けに 追われた人もいた.

柏崎市の建物廃呆物処理処分計画で廃棄物は, 解体現 場で 11 分別 (Figure 3 を参照) 後, 集積場, 若しくは 民間の産廃処理施設一運搬されることになっている. 地 震後, 集積所に搬入された品目は瓦や畳, 破損した木造 軸組等で, その後, 残椬は埋め立てられた. 埋立処分は 県内の民間処分場 (柏崎市) と第3セクター(出雲崎町), 県外の民間処分場（長野県）で処理された。

処理実績に関連し, 地震発生から 2007 年 12 月までの 
建物廃棄物発生量は, 178,216 トンで, コンクリート塊が 最も多く, 次いで廃木材 (角材・柱・板類), 土壁・解体 残渣，瓦の順であった (Figure 3)。資源化では，破砕 コンクリートは再生砕石として舗装材・路盤材・裹込め 材に, 廃木材のチップは燃料化され (Photograph 6〜 Photograph 7), 瓦や解体残椬は直接埋立処分となった.

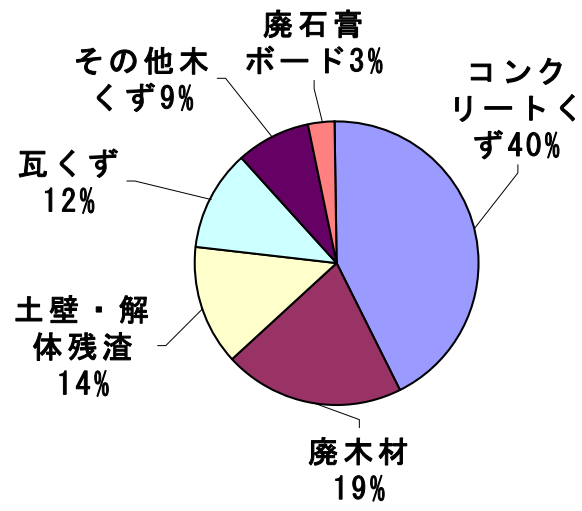

Figure 3 柏崎市の建物廃棄物内訳 (2007 年 12 月まで, 廃棄物の取扱量は 178,216 トン)

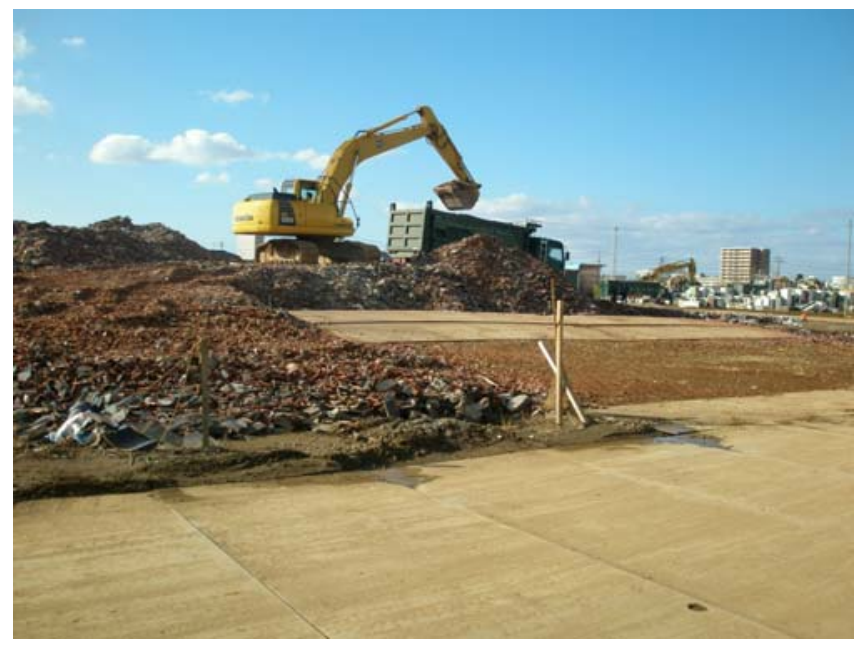

Photograph 6 宝町での瓦類(2007 年 11 月 10 日撮影)

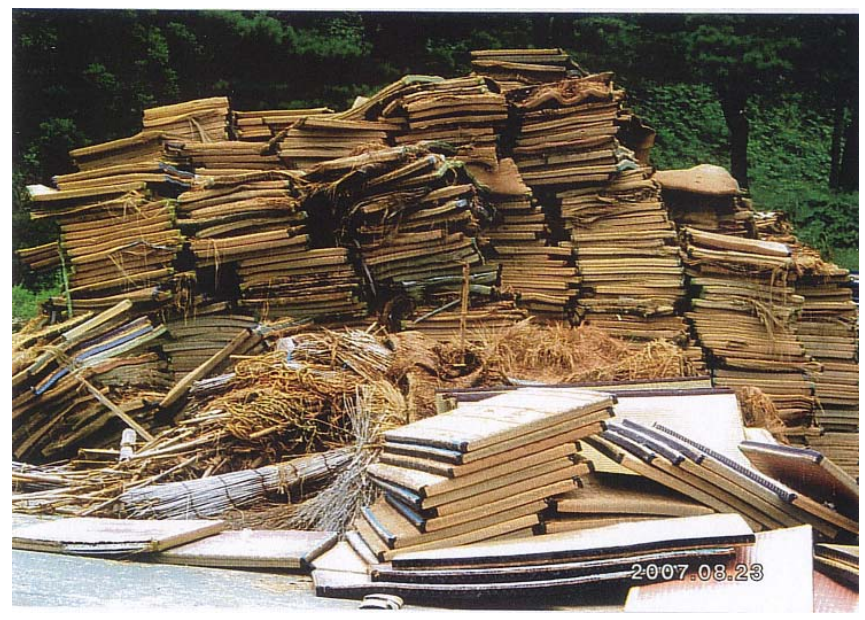

Photograph 7 宝町での曽類（2007 年 8 月 23 日撮影）

\section{（3）柏崎市での住民への周知法}

柏崎市では各家庭に防災行政無線が配備され，これを 利用し，災害廃棄物の特別収集の日程や排出時の注意点 等を市民に提供した. 筆者らの 7 月， 8 月調査でも市内 で聴取され，午前中は炊き出しや「柏崎元気館」での催 事の案内を, 午後 3 時頃にはごみ出しや仮設風呂に関す る情報が放送されていた。 また，7月 30 日付の臨時回覧 として，「広報かしわざき」号外を 1 世帯 1 部配布し，罹 災証明や健康管理に関わる各種相談空口, 廃棄物処理に 際する留意事項の周知徹底を図った。

\section{（4）地震後の柏崎市での廃棄物集積 - 処理状況}

柏崎市は当初, 家財廃棄物之建物廃棄物は別々の集積 所を開設し搬入した. 家財廃棄物は 7 月 18 日から柏崎市 宝町の工場跡地を集積所として利用した. 約 6ha の当該 跡地は市有地で, 国道 6 号線と JR 柏崎駅に挟まれ, 周 辺には住家がある 1 等地である. 当該場所は 2008 年 1 月 30 日まで開設された.

建物廃棄物は，8 月 6 日〜 10 月 6 日に柏崎市鯨波のク レ一射撃場（約 3.5ha）を集積所として利用し，その後， 10 月 15 日以降は家財廃棄物と同じ宝町の集積所内に 2008 年 1 月 30 日まで搬入された.

2008 年 2 月 4 日以降の状況は, 柏崎市安政町の下水処 理施設の空き地に解体残渣の夕を仮置きする状況まで復 旧させ, テレビ等の廃家電や家財廃棄物は, 「クリーンセ ンターかしわざき」の空き地に置かれ，1 ケ月単位で 1 割のペースで処理されている.

以上，宝町集積所の計画運営は柏崎市が担い，現場の 廃棄物保管業務は産業廃棄物協会柏崎支部に委託してい るが，こうした時間経過に伴う廃充物の種類の推移を整 理することは, 廃棄物処理効率化と処理計画の円滑化に つながる.そこで, 柏崎市宝町の集積所の廃棄物の配置, 敷地測定を 8 月 18 日, 9 月 21 日, 10 月 11 日に実施した.

8 月 18 日の調查 (敷地は $200 \mathrm{~m} \times 320 \mathrm{~m})$ では, 第 1 回 目の不燃・粗大ごみ特別収集が 8 月 12 日に終了した直後 で，大量の廃棄物が渾然と搬入されていた. 処理場搬出 は, 廃家電を除く不燃・粗大ごみは 8 月 15 日から, 廃家 電の 8 月 20 日から業者への搬出開始時期を考慮すると, 全体に占める不燃ごみや廃家電の割合が 8 割以上に達し ていた. 9 月に筆者らが携わった廃家電の計数調査では テレビ（大半がブラウン管タイプ） 11,450 台, 冷蔵庫・ 冷凍庫 2,121 台, 洗濯機 753 台，エアコン 956 台であっ た. その後, 9 月下旬に可燃性ごみが焼却処分された.

10 月 11 日の調查結果より, 第 1 回・第 2 回の特別回 収が終了し, 処理施設への搬出作業の開始に伴い，8 月 18 日と比較して, 不燃物や可燃性粗大ごみ, 廃家電等の 廃棄物が約 3 割減少していた. 建物廃棄物の集積所（宝 町）への搬入は 10 月 15 日からの開始となっていたが, 
実際には廃什器, 廃石膏ボードや土壁, 瓦が搬入された. 整頓が進んだ 9 月 21 日と比べ廃棄物の配置にばらつきが 見られたが，これは不然性粗大ごみの中で再分別が途上 段階だったことによる．2008 年 1 月末の閉鎖時には，一 部の家具やベッド等を除き家財廃棄物は集積所から搬出 され，建物廃棄物の仮置きに供された。

\section{（5）柏崎市での集積所の環境対策}

環境問題への配慮から, 地震直後から集積所では騒音 測定が実施され (結果は環境基準内)，ごみ飛散防止ネッ トが敷設された（Photograph 8). ただ，搬入車両の通 路には鉄板が使用され (Photograph 9), 斜面災害抑止 のため, 廃棄物管理に供されるブルーシートが不足し

(Photograph 10), 各廃棄物は土の上に直に配置された

(Photograph 11). その後，直ちに県から指導を受け， 鉄板上に廃家電が配置されることになった。

2007 年 10 月 11 日の現地調査では, 一部の廃家電のみ が鉄板の上に配置され，同年 11 月 10 日の調査から，ほ ぼ全ての廃家電が鉄板の上に移動されていた，その他， 鈆直遮水工の止水コア工法と鋼矢板工法がなされていな い箇所で，調査を重ねるごとに水溜まりが確認された。 実際，搬入車両のタイヤ跡に生じた水溜まりや廃棄物の 荷重によって凹みにできた水溜まり，仮置きされている 廃棄物から染み出した油が浮いている水溜まり,さらに 藻類が繁茂する例（Photograph 12）も散見された.

環境工学的には，気生藻であるスミレモ（Trentepohlia aurea）が確認された. 緑藻に分類され, 高含水の土壌と ブロック塀に付着する.栄養塩で繁茂する習性に着目し, 国立環境研究所は平成 13～15 年度に，「最終処分場管理 における化学物質リスクの早期警戒システムの構築」プ ロジェクトに着手し, 両生類初期胚, 魚類, 藻類, 甲殼 類の各個体，細菌を用いた急性毒性試験である. 数種の 浸出水で検出された毒性特性より分散生物フロックの効 率的な固液分離処理で個体数が低減 (生長阻害試験), 生 物指標による環境変動把握の可能性が示唆された. 即ち, 低温環境に耐えられる Trentepohlia aurea の繁茂は寒冷環 境下の当該被災地では妥当であり, CN 基等の未検出を 規定した廃棄物処分場浸出水処理で, 藻類が繁茂する ${ }^{13)}$.

Photograph 12 の藻類から, 栄養塩は認められるものの, 有害物質に敏感なこの藻類の存在は環境影響が少ない点 の証左と言える.

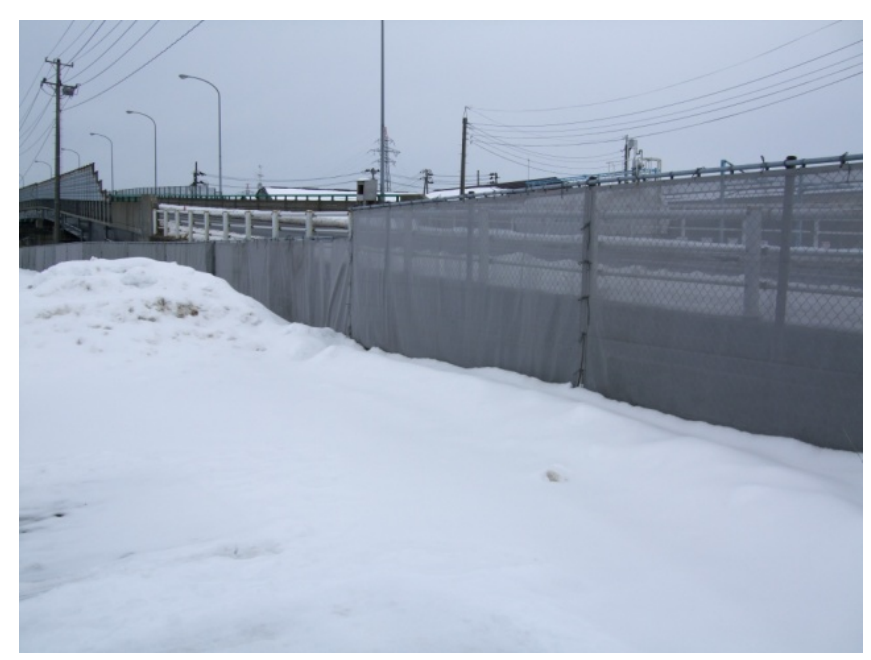

\section{Photograph 8 宝町集積所に敷設のごみ飛散防止ネット}

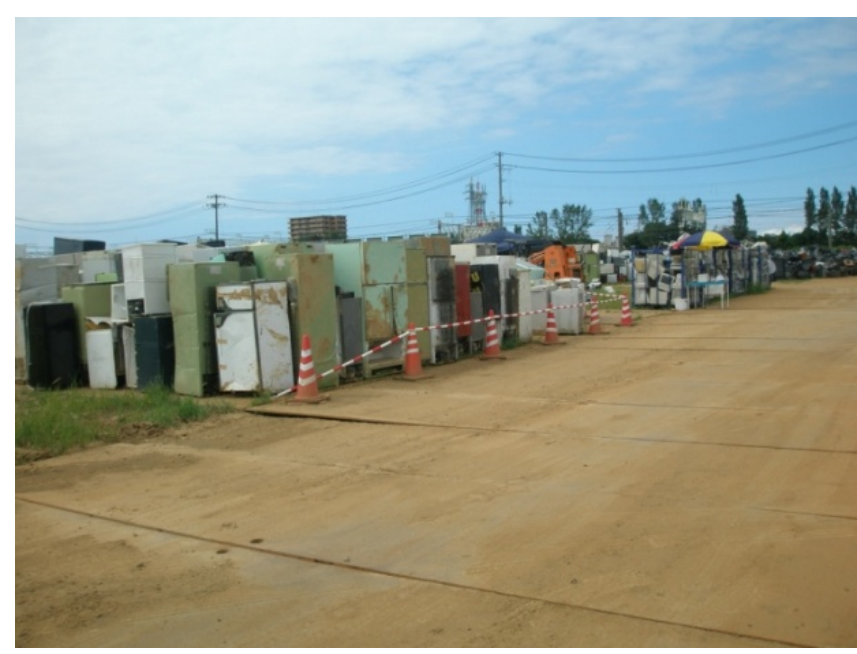

Photograph 9 宝町集積所の鉄板敷設後の搬入車両通路

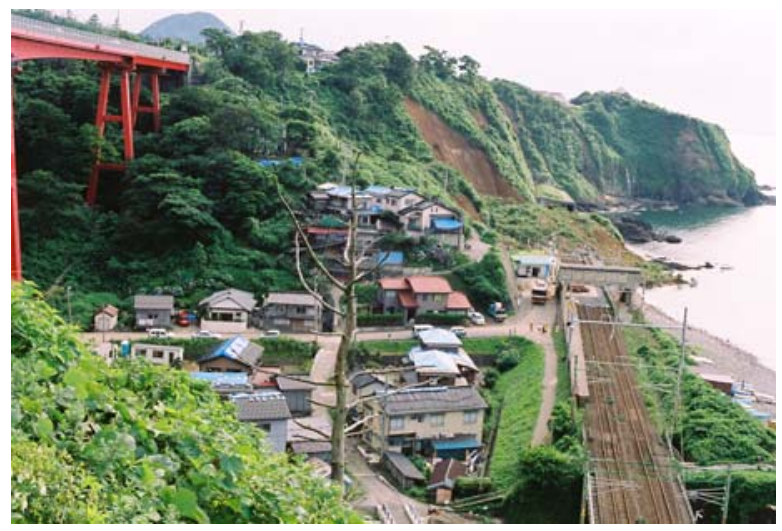

Photograph 10 JR 青海川駅裏斜面の家屋, 亀裂箇所に ブルーシート(2007 年 7 月 19 日撮影) 


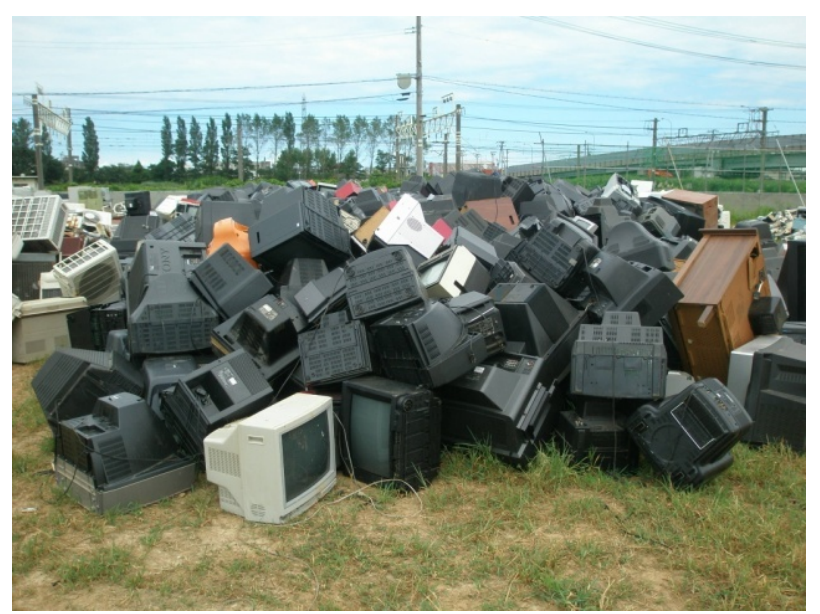

Photograph 11 土に直に仮置きされた廃 TV 群

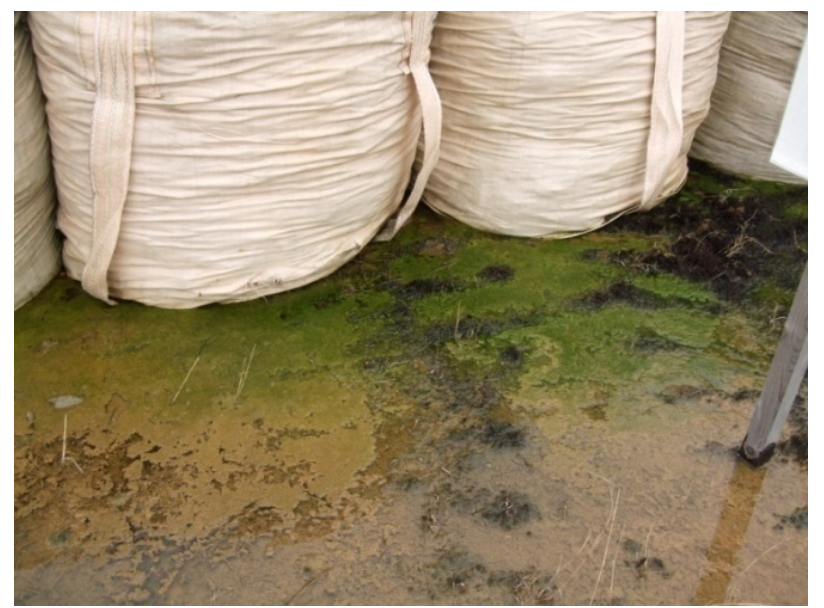

Photograph 12 富栄養化で水溜まりに藻類が繁茂（土 囊と土壤境界の黒色斑状箇所に密生)

\section{3. 刈羽村での現地調查結果}

\section{（1）刈羽村内の家財廃棄物収集 - 処理}

刈羽村では平時の可燃ごみ処理は 1 日おきに回収し, 柏崎市の焼却施設「クリーンセンターかしわざき」で処 理を行っている. 震災により, 同焼却施設が稼動不能と なり， 7 月 18 日〜 11 月 24 日まで長岡市の焼却施設に搬 出した. 柏崎市の同焼却施設の復旧に伴い, 11 月 24 日 以降は通常の処理業務が遂行出来るようになった. また, 同村は平時の収集運般に際し，民間 1 業者に委託してい るが，以前から関係を有するこの処理業者とともに，震 災後, 新たに民間 1 業者を委託した. この背景として, ライフライン途絶で紙コップ, 紙皿, 割り箬, ペットボ トル等の家庭ごみが排出され，恒常的に各ステーション が山積みになっていた点が挙げられる. 民間 2 業者体制 の収集で, 7 月 18 日〜 7 月 31 日は毎日の回収, 8 月 1 日 ～ 8 月 10 日は日曜・祝日を除き 1 日おきに特別収集が行 われ, 8 月 10 日以降は各ステーションから通常通りの家 庭ごみ収集が行われた。

資源ごみとして分別された空き缶，ガラスとビン，ぺ ットボトル, EPS, その他プラスチック, 新聞紙, 杂隹誌,
段ボール，草・剪定枝は地震後も通常通り（週 1 回収， 紙類は月 1 回の回収）の収集がなされた.

不燃ごみは 8 月 27 日まで原則, 回収せず, 被災者宅で の保管とし，保管出来ない場合は指定された 1 ケ所の第 3 セクター処理施設と 1 ケ所の民間処理業者の委託業者 に搬入する措置を講じた. 割れたガラスや瀬戸物類は 8 月 13 日〜8 18 日に地区ごとに収集され，それ以外の 不燃ごみは8月 30 日以降, 通常通りの収集で対応された.

テレビ・冷蔵冷涷庫・エアコン・洗濯機の家電 4 品目 を除く粗大ごみは, 地震後は通常の収集が不可能となり， 刈羽村では被災者を対象とした廃棄物別の個数を把握し， 計画的に収集した. 8 月 13 日〜 8 月 18 日の 1 回目， 10 月 9 日〜 10 月 31 日の 2 回目として地区ごとに収集が行 われた. 1 回目の回収以前には基本的に回収せず, 被災 者宅で粗大ごみを保管することとなり，保管出来ない不 燃ごみと同じ措置が講じられた. 収集に際しては, 各被 災者宅の庭先とした. 刈羽村では全世帯の 4 割超が半壊 以上と查定され， 1 棟につき軽トラック 1 台分の粗大ご みが発生した. ただ，明らかに使える物品も含まれ，役 所側は被災者のモラルを信じたい, と話していた.一方, 家電 4 品目も粗大ごみと同様, 被災者に発生個数の調査 を実施し，10月 9 日〜 10月 31 日に地区ごとに収集が行 われた. 10 月の回収まで保管出来ない被災者は個人で電 気店に処分を依頼した．これ等に要した運搬費 - 処分費 は刈习习村に請求すれば返却されるものであった。

刈羽村の家財廃棄物処理処分計画では木屑, タイヤ, 廃家電等 11 品目に分けられ, 集積所, 若しくは処理業者 に搬入されることになっている. 木屑は破砕処理後に然 料化 (Photograph 13), 繊維屠や紙屑は燒却処理によっ て減量化，焼却灰は埋立処分となる. 埋立処分される廃 棄物は, 県内 1 ケ所の第 3 セクタ一処分場（出雲崎町） と県外 1 ヶ所の民間処分場(長野県)で埋め立てられた。

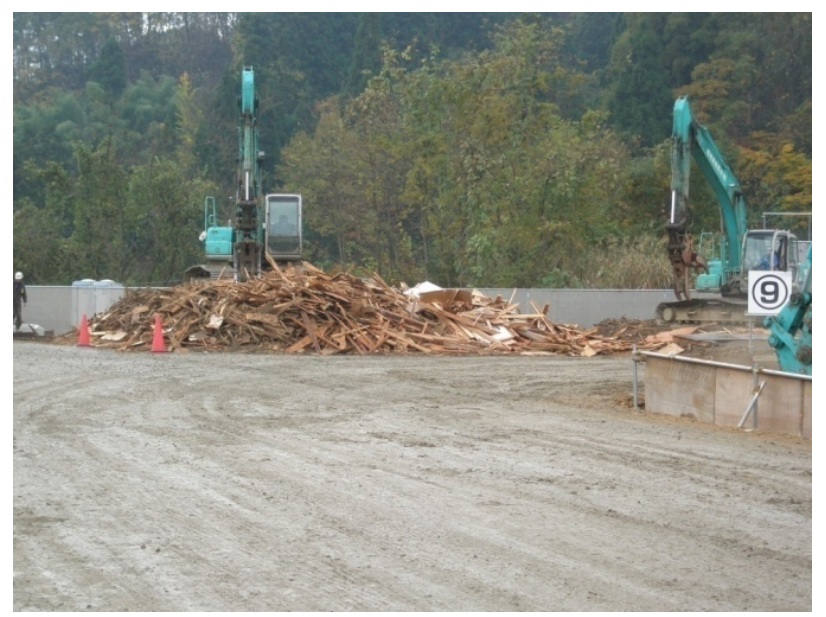

Photograph 13 2ha の集積所に仮置きの木屑（刈羽村） 


\section{（2）刈羽村内の解体廃棄物（建築廃材）収集 - 処理}

建物廃棄物に関しては, 7 月 23 日から指定登録業者の 受付・解体作業が開始された. 原則, 混載は認めず解体 現場で分別され, その後, 刚羽村油田地区に開設された 集積所に搬入された. ただ, 解体家屋の分別が困難と村 が認定したケース（混合搬入認定証を発行）や，廃棄物 が少なく荷台の前後で分別積載が出来る場合に限って混 載を認めた. 建物廃棄物の処分費で解体・修繥費全般, 一部損壊の修理・修繥に係る運搬費は自己負担ながら, その他の収集・運搬・処分費は全額村が負担した.

これに関連し, 刈羽村の建物廃棄物処理処分計画では, 解体現場で 18 分別 (金属屑, コンクリート塊, 長尺, 廃 プラスチック, 金属サイディング, 畳, 木屑, 紙屑, 蕫, 断熱材, 瓦, ガラス・陶磁器, 非飛散性アスベス卜, 土 壁, 木毛板, 廃石膏ボード, 解体残渣, その他) 後, 各 品目は集積所一運般され, 一時的に仮置き後に各処理施 設, または処分施設に搬出されることになっている. 埋 立処分の廃棄物は, 県内 1 ヶ所の処分場（柏崎市）之 1 ヶ所の第3セクター処分場 (出雲崎町) で処理される.

地震発生から 2007 年末までの建物廃棄物発生量は, 24,155 トンで, 平成 16 年度の刚羽村の一般廃棄物量の約 12 倍に達した. 同村が集計した結果で品目別には, コン クリート塊が最も多く, 次いで木屑, 瓦, 解体残椬で占 めた (Figure 4). なお，コンクリート塊や木屑は破砕 処理後に資源化され，コンクリートは再生砕石として舗 装や路盤材, 土木構造物の裏込め材に, 木屑はチップ状 に処理後, 燃料化されたが (Photograph 13), 瓦や解体 残椬は直接埋立処分された (Photograph 14).

\section{（3）刈羽村での住民への周知法}

㺫羽村は原子力発電所の関係上, 平時から全世帯に防 災無線が設置され，災害情報を村民に提供した．筆者ら が調査した2007年8月初旬には大雨情報が流されていた. また，全世帯に光フィイバーが導入されており，インタ 一ネット経由でも情報入手が可能であったが，同年 11 月中旬に仮設住宅の住民に聞いたところでは, 高齢者に とっては使い方が分からず防災無線の音声も聞き取りに くかったようである. 廃棄物を含む災害関連情報につい ては, 7 月 20 日〜8 月 24 日の期間, 毎週金曜日に回覧板 情報を全世帯に配布し, 周知徹底が図られた.こうした 情報はチラシとして仮設住宅の集会場にも置かれ，住民 同士で確認出来るシステムとなっていた.

\section{（4）地震後の刈羽村での廃棄物集積 - 処理状況}

8月 27 日からの一時受け入れに際しても分別が原則と され，仮設住宅入居に伴い，引越し作業で親戚や子女の 支援を受けながら効率的に処分された（後述アンケート のFigure 7 で3 割).ただ, 集積場所は刈羽村大字油田

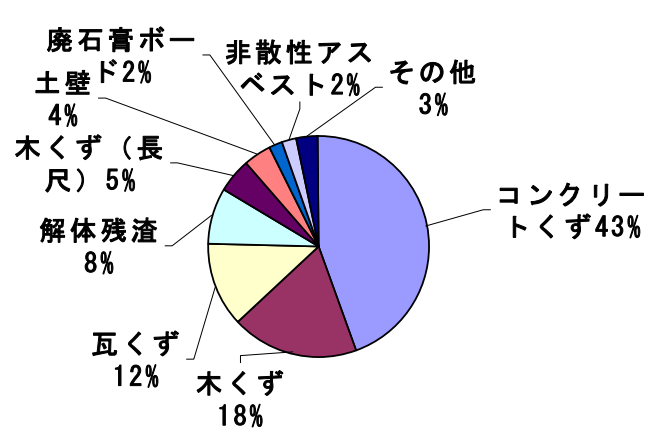

Figure 4 刈羽村の建物廃棄物内訳 (2007 年 12 月まで, 廃棄物の取扱量は 24,155 トン)

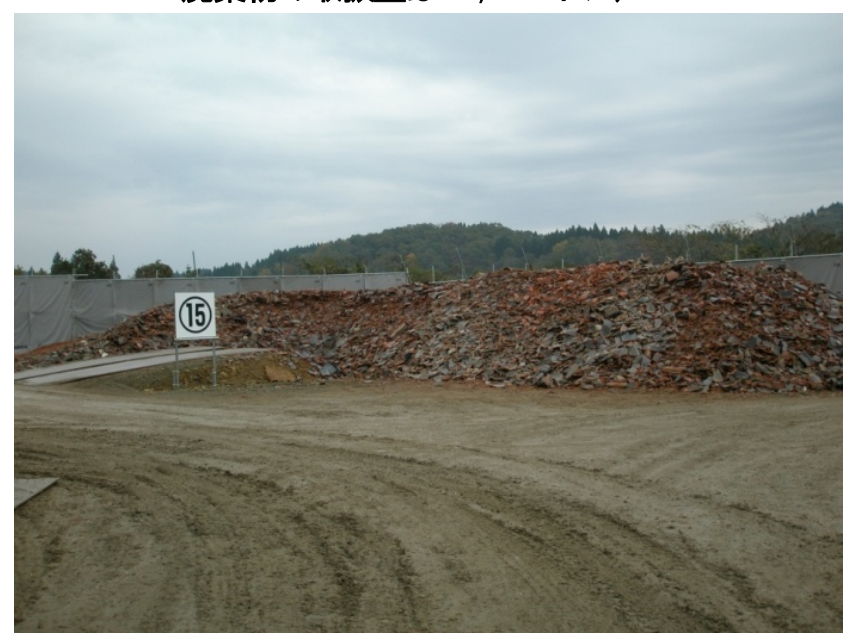

Photograph 14 集積所に仮置き後, 埋立処分される屋 根瓦（刈羽村）

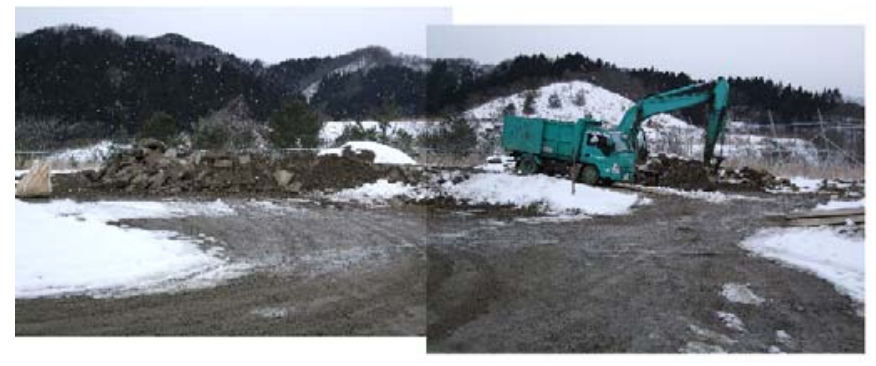

\section{Photograph 15 刈羽村大字油田の集積所（主にコンク リートが搬入. 2008 年 1 月 23 日撮影)}

地内にある民有地の一部（約 2ha）が使用されたが，山 中のため運搬自体に労力を要した (Photograph 15).

Photograph 15 の集積所は 2 年間, 利用することを目 的として刈羽村が借り上げ, 実際の廃棄物仮置き面積 $16,305 \mathrm{~m}^{2}$ と想定した計画が運用されている。 なお， 8 月 27 日まで災害廃棄物の搬入は民間業者 1 社に委託し, 並 行して集積所の計画・整備を進めていた.

建物解体, 若しくは修繥で発生した建築廃材のみがこ の集積所に搬入, 仮置きされた. 不燃・粗大ごみは直接, 
各請負業者に搬入し，テレビや冷蔵庫等の家電 4 品目は 同集積所が狭いため, 長岡市の業者所有地を 2 ケ月間借 用して対応した. 集積所計画・整備は随意契約により, 8 月 27 日までの災害廃棄物の搬入先である民間業者とは 別の民間業者 1 社によって行われた，随意による双務契 約のこの民間業者は, 2004 年新潟県中越地震時に被害を 受けた長岡市での集積・処理業務の経験を有し，保管管 理業務も委託，解体計画書，及び指定運運搬業者確認， 廃棄物の選別・移動，安全管理を行った。

油田地区の集積所設置で，事前に役場，保健所及び県 が協議し，周辺住民に説明会を開催し合意のうえで決定 した，付随項目として，災害廃棄物処理業務は平成 22 年 3 月までの予定とし，終了後は現状復旧する旨が申し 合わされた.

\section{（5）刈羽村での集積所の環境対策}

刚羽村の集積所では，ごみ飛散防止ネット敷設

(Photograph 16), 水質検査, 騒音・振動測定, アスベ ス卜調査が月 1 回実施され，この取り組みは 2008 年 2 月時点でも継続中で, 特段の問題は発生していない.

油田地区の集積所は民有地のため，土地返却時に現状 復帰が前提となり，ポリプロピレン䋊維の遮水シートを 敷き，その上に土を被覆し集積所全体を舗装した。この 造成敷地では周辺対策が求められ，シートの他，油分浸 出抑制のため鉄板やアスファルトも施工された. 雨水や 污濁水は遮水シートで防ぎ，U 字溝やパイプ溝

(Photograph 17) を通過させ集水槽（Photograph 18） に注がれ，沈砂後に油水分離槽（Photograph 19） 八送 られた. 油水分離槽の水は油分除去後, 大腸菌群が滅菌 処理され, 放水させる. 集水槽は月 1 回の水質検査が実 施され，2008 年 2 月時点でも継続されている.

筆者らが 2007 年 11 月に同村仮設住宅のリーダーへ聞 き取りをしたところ，行政の環境配慮を契機に，住民間 でも分別に向けた話し合いをしていることが分かった。

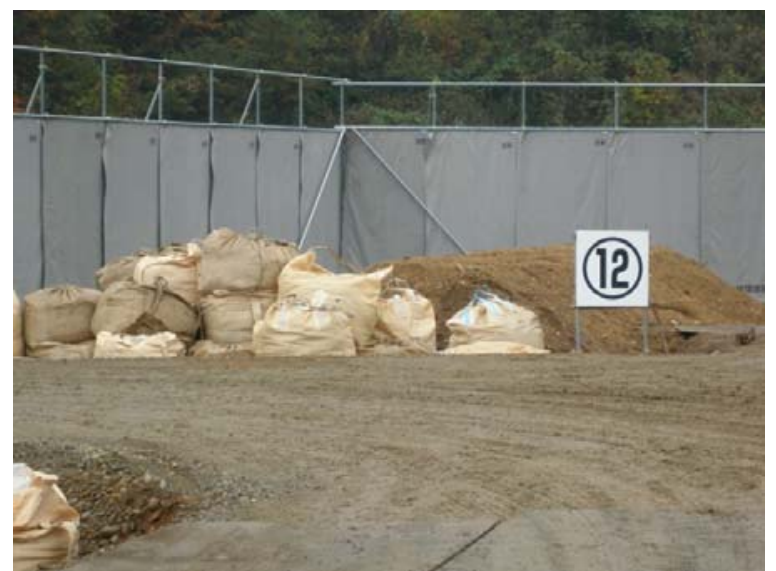

Photograph 16 油田地区集積所に敷設の防音性の高い 飛散防止ネット（2007 年 11 月 10 日）

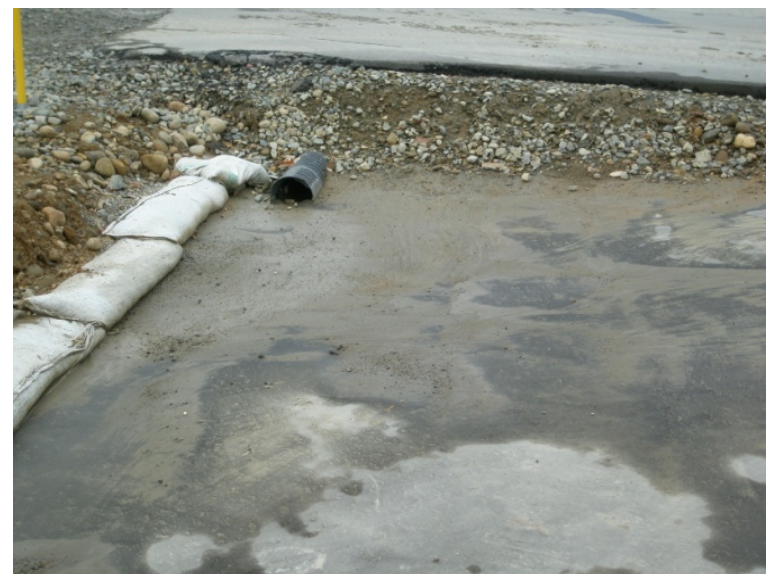

Photograph 17 同地区集積所に敷設されたパイプ溝

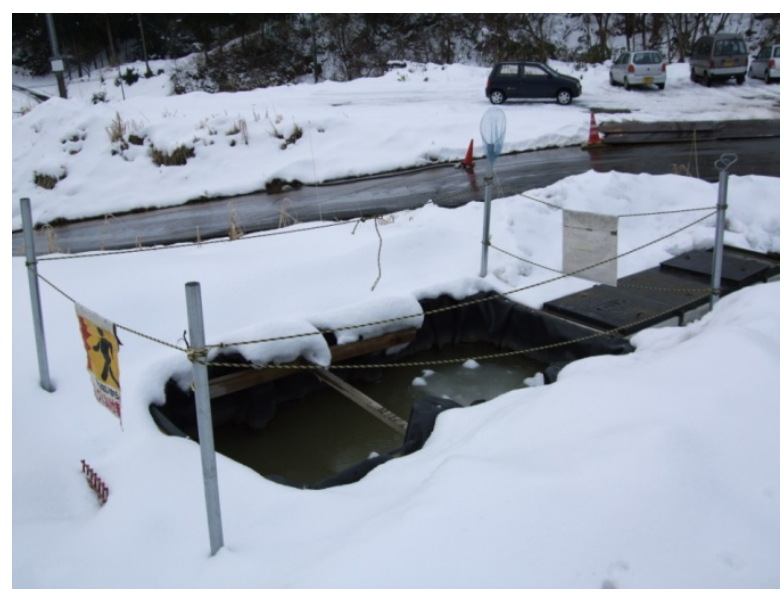

Photograph 18 同地区集積所に敷設された集水槽

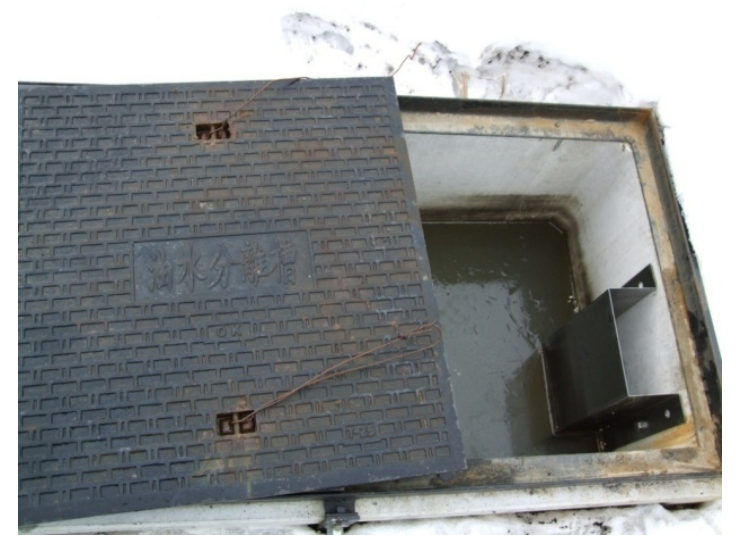

Photograph 19 同地区集積所に敷設の油水分離槽

\section{3. 刈羽村住民への廃棄物処理に係るアンケート調 査}

Table 2 に示した行政の緊急対応のフローを鑑み，住 民アンケートを 2007 年 12 月に行った。災害関連では通 常，避難に係る項目，若しくは災害医療や健康状態が質 問される ${ }^{14)}$ が，ここでは災害廃棄物に焦点を当てた防災 科技研の先見事例を踏まえ ${ }^{15)}$ ，実施した。 
Table 2 現地調査に基づく柏崎市と刈羽村での震災廃棄物対応の流れ

\begin{tabular}{|c|c|c|}
\hline 地震後の収集処理，啓発，環境に係る項目 & 柏崎市の現況 & 刈羽村の現況 \\
\hline $\begin{array}{l}\text { 被害概要等 } \\
\text { (人口総数は2 } 2006 \text { 年 } 10 \text { 月 } 1 \text { 日時点) } \\
\text { (建物被害状況は } 2008 \text { 年 } 7 \text { 月 } 15 \text { 日時点) }\end{array}$ & $\begin{array}{l}\text { •震度 } 6 \text { 強, K-NET (NIG018) 最大化速度 } 812 \mathrm{~cm} / \mathrm{s}^{2}, \\
\text { 人口総数 } 94,317 \text { 名 } \\
\text { ·28,345 棟 (全壊 1,120, 大規模半壊 } 676, \text { 半壊 } 3,888, \\
\text { 一部損壊 22,661), 非住家 } 24,323 \\
\end{array}$ & $\begin{array}{l}\text {-震度 } 6 \text { 強, 人口総数 4,798 名, 家屋 1,333, 事業 } \\
\text { 所や公共施設等の非住家総数 } 2,839 \text { 棟 } \\
\text { ·1,261 棟（全壊 } 166, \text { 大規模半壊 } 136, \text { 半壊 } 305 \text {, } \\
\text { 部損壊 654), 非住家 } 2,228\end{array}$ \\
\hline 家財廃裹物収集・処理 & 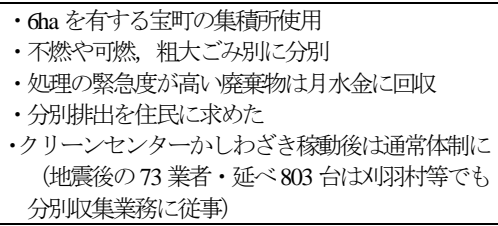 & 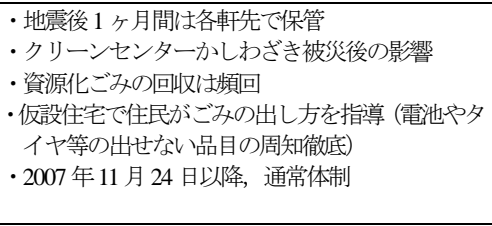 \\
\hline 解体廃亜物・建築廃材収集・処理 & 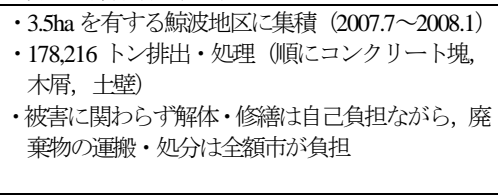 & 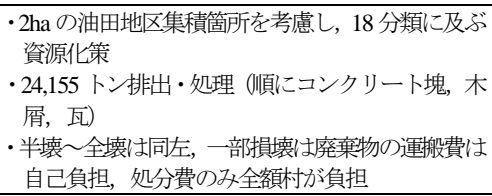 \\
\hline 住民への周知法 & ・「広報かしわざき」と朝夕の防災無線活用 & $\begin{array}{l}\text { ·防災無線と各世帯の光ファイバー活用 } \\
\cdot 7.20 \sim 8.24 \text { は各世帯に毎週金曜日に回覧板, } 11 \text { 月 } \\
\text { の調查で仮設住宅集会所にも掲示 } \\
\end{array}$ \\
\hline $\begin{array}{l}\text { 地震後の廃衰物集積・処理状况 } \\
\text { (主に管) }\end{array}$ & $\begin{array}{l}\text { •家電製品の計数調査で各品目が } 1 \text { 万台前後, 集積 } \\
\text { 所内で順次, 処理 } \\
\text { •ベッドやマットレス, 自転車が野ざらしに }\end{array}$ & $\begin{array}{l}\cdot \text { ·油田地区の集積所は山中で, アプローチ困難, } 8 \\
\text { 月の調査で被災住宅軒先に散乱状態 } \\
\text { ·多くの家電製品は長岡市で処理された }\end{array}$ \\
\hline 集積所における環境対策 & $\begin{array}{l}\text { •ごみ飛散防止ネット敷設 } \\
\cdot \text { 集積所内車両通行箇所に鉄板敷設 } \\
\cdot \text { 斜面防方災用の遮水用ブルージートが不足 } \\
\cdot \text { 集積所内水溜りに藻類繁茂 }\end{array}$ & $\begin{array}{l}\text { ·防音性を施したごみ飛散防止ネット敷設 } \\
\text { ·油水分離慒等, 水処理に力点 } \\
\text { •遮水シート上に土を被覆 }\end{array}$ \\
\hline 地盤工学的な対策 & 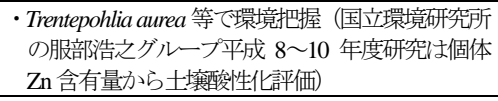 & $\begin{array}{l}\text { •アアスファルト塊由来油分のシート, ベントナイト } \\
\text { 層による遮断, 油成分の分離や吸着 }\end{array}$ \\
\hline 今後の課題 & $\begin{array}{l}\text { ·仮置場, ゴミステーションが判然としないケース } \\
\text { も } \\
\text { ·廃アスファルト, 古タイヤから油分浸出 } \\
\text { •大量のウレタン放置 }\end{array}$ & 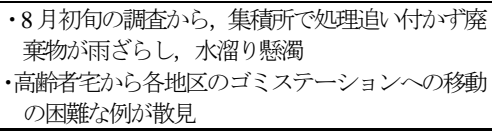 \\
\hline
\end{tabular}

同村選定理由は, 地震後に柏崎市等への一時的な避難, 200 世帯を凌駕する仮設住宅入居, 2004 年・ 2007 年の地 震で 2 回の被災にある. 地震後の現地調査で, 地域住民 の中には中越地震で新築家屋が被災, 修繬後に再び被害 を受け，生活再建不能といった話が聞かれた.こうした 点と重なり, 2004 年 11 月 19 日に村内初の大型スーパー マーケット「PLANT-5」（本社は福井市, 福井・石川・ 富山・新潟・福島・岐阜・鳥取に展開）が開店するもの の, 2007 年 8 月 3 日の取締役会の議で, 同 9 月 20 日に 閉店する等, 正社員 28 名とパート 166 名の離職を余儀な くされ, 柏崎公共職業安定所で雇用対策推進協議会が胎 動したことを重く受け止めた. 他方, 柏崎刚羽原子力発 電所火災による不測の事態に接し，住民行動を探ること も危機管理上，有意義と判断した.

調査は，㺫羽村の源土運動広場にある 200 棟の仮設住 宅を選定し，親戚宅や自宅を中心に生活する世帯を除い た 150 軒に質問紙を郵送，返送してもらった。 回収数は 63，多肢選択で回答. 質問内容は廃棄物処理を中心に， 地震時に困った点や健康状態等である. フェースシート は無回答が見られたが，圧倒的に男性で，4分の 3 が 50 代以上と偏った. ただ，家族の中核となる層の生活再建 の軌跡が感じ取れることから，分析した.

先ず，地震で困った点は後片付けと断水が最も多く, 次いでガス停止, 3 割強が瓦やブロック塀, 家具, 家電
の処理に追われ, 2004 年新潟県中越地震でも少数ながら, 什器被害で廃棄物が発生した. 両地震とも約 4 割の回答 者が家族で集積所に運搬し，ヒアリングより日頃から協 力体制の確認を重ねていた，また，前回の地震で 1 割が 行政に処分を依頼した (Figure 5〜Figure 7).

度重なる災害に見舞われ，ボランティアへの期待感の 高まりとともに，半数がリサイクル推進・処分場整備を 挙げている. ただ，不法投棄の話を聞いたり野焼きを見 た人が少ないながら存在することは注目された。また， 大気・水・土㙥環境への影響に危機感を募らせる人も多 $<$, 阿賀野川流域の第二水俣病の伝聞が小学校から行わ れている点は堅持させたい (Figure 8～Figure 10).

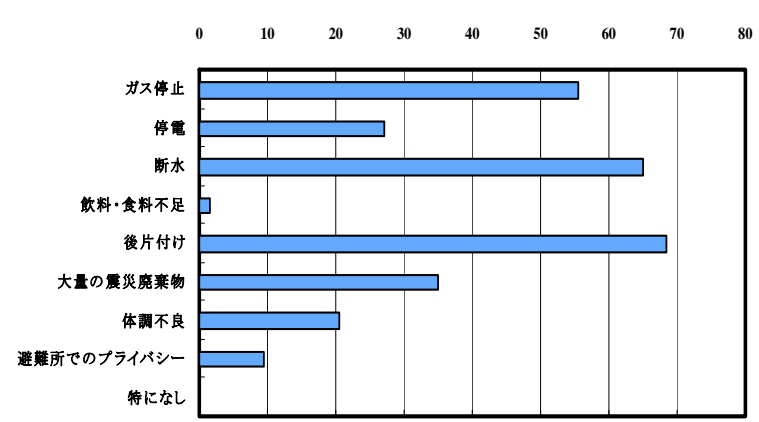

Figure 52007 年中越沖地震で困った点（複数回答, \%) 
口2007年 2004 年

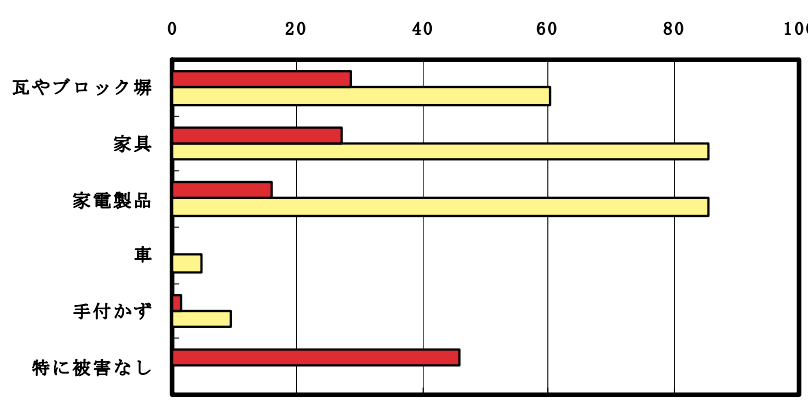

Figure 6 地震時に実際に処分した品目（複数回答，\%)

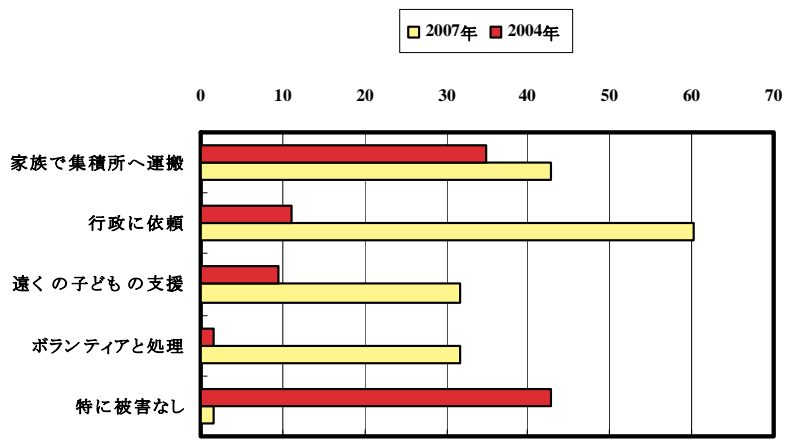

Figure 7 地震時の廃棄物処理方法（複数回答，\%)

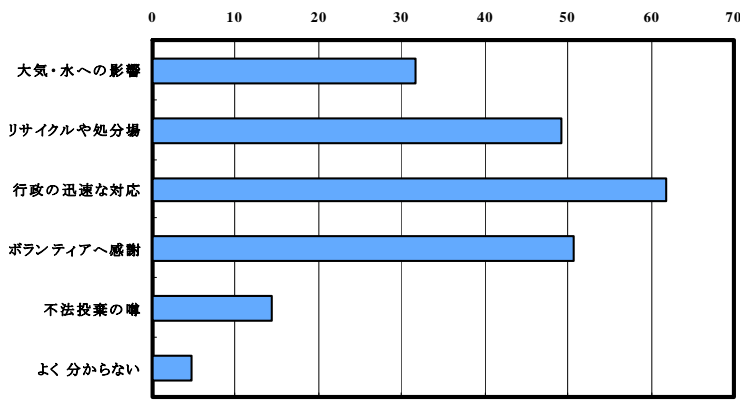

Figure 8 大量の廃棄物に感じたこと（複数回答，\%)

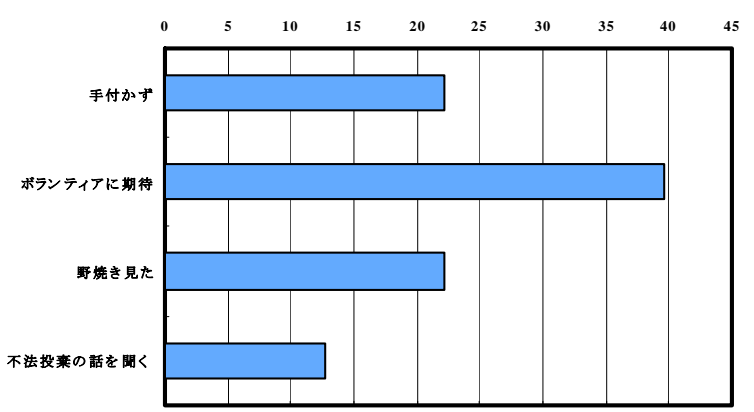

Figure 9 廃棄物処理で体験したこと（複数回答，\%)

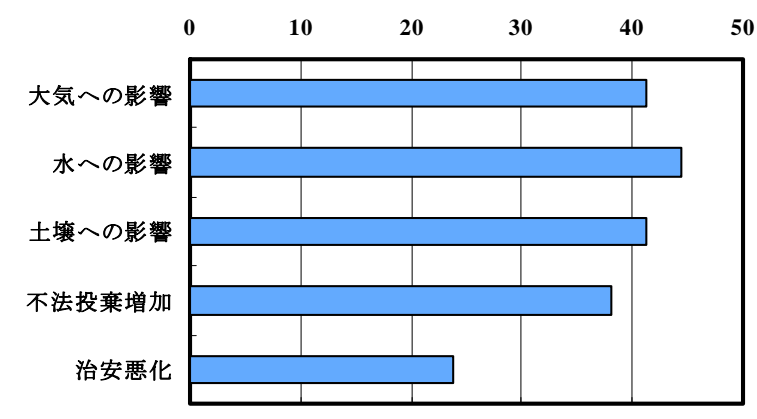

Figure 10 地震後の環境問題の懸案事項 (複数回答, \%)

\section{4. 災害時の廃棄物対策の課題}

\section{1. 廃棄物処理における自治体間の連携}

年間処理量が倍増する激甚災害時に，復興の円滑化に 向けて神戸の事例が参考となる. 震災から同年 8 月集計 の全壊 - 半壊, 全焼 - 半焼家屋棟数の合計約 9 万 4 千棟 から，撤去を要する災害廃棄物量は神戸市全域で約 1 千 4 百万 $\mathrm{m}^{3}$ (1995 年 4 月推計) に達した. 平成 7 年度中の 解体撤去, 及び平成 8 年度中の処理処分完了のため, 仮 置場への搬入と分別，焼却施設整備を進めた結果，平成 10 年度には通常の廃棄物処理業務に戻った ${ }^{16)}$.これはボ ランティアの協力と住民の分別回収による.

平成 15 年に徳島県勝浦郡上勝町 (県庁の南西方向約 $40 \mathrm{~km}$ に位置する農業地域) で「ゼロ・ウェイスト宣言」 を打ち出し，家庭ごみを含む廃棄物分別收集で 34 分類に 細分化し，リサイクル率は 80\%（環境省まとめの 2004 年度リサイクル率で，全国平均 $17.6 \%$, 新潟県 $18.4 \%$, 長野県 $23.6 \%$, 富山県 $18.9 \%$, 石川県 $15.2 \%$ ）に達して いる.この宣言では災害時にも相互協力で排出を抑え， 2020 年までに埋立処分ゼロを目標に掲げている.

東京都も自治体相互の連携を軸として，災害時の廃棄 物対策を定めるに至った. 都が平成 17 年 2 月 25 日の「首 都直下地震対策に係る被害想定結果について」の地震シ ナリオで, 4,000 万トン (中央防災会議, 首都直下地震の 第 13 回会議資料では 8,300 9,600 万トン) の瓦碩発生を 見込んでいる. 危機管理面から 2007 年中越沖地震後, 特 別区清掃リサイクル主管課長会を中心に, 各区派遣の清 掃車両と人員を調整し, 粗大ごみや可燃ごみ処理を 8 月 27 日〜9 月 8 日に支援した. 各区から延心清掃車等 26 台（小型プレス車 15 台・新大型特殊車 4 台・連絡車 7 台）と職員 72 名を, (社) 東京環境保全協会から, 清掃 車（新大型特殊車） 1 台を派遣している. 家庭排出の可 燃ごみを集積所から収集，仮置場まで運搬し，仮置場か ら県内の他自治体の清掃工場に運搬寸る作業に従事した. 国分寺市と多摩市は数台の車両と十数人の職員を, 東京 廃棄物事業協同組合も延べ 89 台・108 人を派遣した ${ }^{17}$. 


\section{2. 災害廃棄物を考慮した環境関連技術の動向}

今回の地震後, 新潟県は柏崎市内で 2007 年 7 月 18 日 に鯖石川と鵜川で水質調查を実施し，環境影響は見られ なかったことを確認している. 但し, 各種廃棄物の半年 にわたる屋外保管が予見され ${ }^{18)}$, 筆者らは 2000 年以降, 新潟県の海岸部で漂着物とその焼却物の多さに接し, 土 㙵環境調查を実施してきた (環境庁告示 46 号試験). 2007 年中越沖地震後のプラスチック類の仮置き同様, 屋外曝 露 (出雲崎町や柏崎市等の海岸で毎年 12 月〜 月 月は手付 かず）に着目し，地下浸出の可能性を視野にモニタリン グしている. 2003 年に実測した新潟県内の海岸砂は, 溶 出試験法による重金属濃度で, Pb0.03〜0.1，Cr0.1～0.6, Cd0.04 0.1ppm, Cr を除き環境基淮值以下だった. ただ, 焼却灰は有害物質が濃縮するため, 適正処理の一つとし て新たな試みを行った，具体的には漂着した魚縄を焼却 せずに細かく裁断し，それをセメント混合するものであ る. 結果的には盛土材としての実用性が示唆された ${ }^{19)}$. その意味では筆者らが取り組む研究を契機に, 建設廃材 の有効利用へつながることが期待される.

一方, 地震後には柏崎市宝町の集積所でブラウン管TV 群 ${ }^{20)}$ が目立ち, かつて絶縁油として使用のポリ塩化ビフ ェニールが懸念された (Photograph 11). また, 廃蛍光 灯も見られたことに関連し, 1999 年に東京や青森の文教 施設で PCB 使用のコンデンサの老朽化で爆発した事例 等が想起される ${ }^{21)}$.こうした諸問題が浮上寸ることで, 技術開発の起爆剤となる側面もある。2007 年 8 月には, 国内初の PCB 污染土㙥净化施設 (年間処理能 1700 トン) が稼動し, 処理の流れは土㙵破砕後に筒内で $800^{\circ} \mathrm{C}$ 前後 に加熱し, 固体燃焼で生成された気化ガスをさらに加熱 後, 酸素吹き込み燃焼により $1,000^{\circ} \mathrm{C}$ 以上に熱し, この工 程で得られた残椬をフィルター通過させることで PCB を基準值以下に抑制，処理費を低減出来る ${ }^{22)}$.

但し, 分別回収が第一義となり, 情報提供の重要性 に関連して, 排出総量原単位（g/人・日）の 20 40\%削 減効果 ${ }^{23)}$ が認められ（2000 年～2001 年, 千葉市 250 人 モニター調査), 行政やマスコミを通じた啓発の重要性が 示された. また, 横浜市でも分別を徹底させ（食物残椬 等の生ごみや可燃物, 蛍光灯といった不燃物, 缶やペッ トボトル, 小さな金属類, 乾電池, スプレー缶, プラス チック製品, 古布や古紙, 粗大ごみ), 年間ベースで経費 が億単位, 2001 年と 2005 年の比較で 3 割の減量効果が 各新聞の県版で報道され，環境負荷低減に向けた意識面 で好循環となっている. 本研究の目的の一つとして, 環 境防災に対する各人の関心を励起させることにある.

\section{5. おわりに}

中越沖地震後, 柏崎市と刈羽村では 2〜3 ケ月間は災害 廃㶳物発生量がピークを推移し, 2008 年 2 月時点で家財 道具等の処分はほぼ終了し, 建物解体に伴う廃棄物処理 に移行した. こうした災害時の取り組みを詳細に調査し た結果，以下の点が明らかとなった。

（1) 廃棄物処理量が倍増し, その大半が産業廃棄物扱い の建築廃材であった. 地震後の片付けで, 統括指揮 権を持つ各被災自治体は処理に追われ, 解体・運 搬・処理に際し, 他の自治体や民間業者への要請で 乗り切った.

(2) 中越沖地震ではクリーンセンターかしわざきが被 災したため, 収集体制の維持が困難となり，2007 年 11 月まで可燃ごみを他自治体一搬出した. 特に 刈羽村ではライフライン途絶で, 紙コップ, 紙皿, 割り箬, ペットボトルが急増した. 柏崎市の集積所 内は地震から 2 个月間, 同村の廃棄物とともに, 建 物廃棄物も搬入されたが, 長岡市の施設利用により, 急場を凌いだ.

(3) 㺫羽村住民アンケートで, 2004 年の地震後は軽微 な建物被害で済んだが，2007 年中越沖地震ではコ ンクリート塊や廃木材処理が膨大となった. 新潟県 柏崎市・同刈羽村とも, 災害廃棄物対策計画が胎動 し, 飛散防止ネット敷設等, 集積所の環境対策は評 価され，質問にある環境影響の懸念に配慮したもの であった。これは自治体, 処理業者双方で前回の 2004 年新潟県中越地震での経験が反映され, 危機 管理意識が醸成されたことがヒアリングより明ら かとなった.

(4) 回答傾向として廃棄物問題に関心があり, 処理で行 政やボランティアへ期待する一方で, 地震後の混乱 期に不法投棄の噂や野焼きに気付く例もあった.さ らに, 2004 年新潟県中越地震時に廃棄物処分に奔 走した人が 1 割いることが判明した. 自らの健康に 不安を抱えながら, 半数弱の回答者が土壌環境を懸 念していた.

(5) 被災自治体と支援する側も, 分別回収を前提とした 迅速な廃棄物処理を第一義とする一方で, 環境モ二 タリングを積極的に進める趨勢で, 企業も環境安全 性にシフトした技術開発を活発化させている. 現状 ではリサイクルが容易な建材・什器の而震化が期待 される.

一連の調査から, 住民協力の分別でごみ減量化に直結 寸るものの, 仮置場での屋外暴露を鑑內, 筆者らは海岸 部の重金属污染を例に，環境影響の可能性に言及した。 


\section{参考文献}

1) John Langone (1989) : A Stinking Mess, TIME. pp.32 - 34. 1989.1.2.

2) 福林良典, 木村亮 (2007) : パプアニューギニア農村部で の「土のう」による住民参加型未舗装道路整備手法の適 用, 地盤工学ジャーナル. Vol.2. No.3. pp.209-221.

3) (財) 阪神・淡路大震災記念協会 編 (2005) : 『阪神・淡 路大震災 10 年一翔ベフェニックス 創造的復興への群像』, 兵庫ジャーナル社. 全 780 頁.

4) 木村智博, 神田順, 三橋博巳, 青山清道 (2003) : 降積雪 量の変動に基づく事故の相関分析と今後の防災対策, JCOSSAR'03 論文集. 日本学術会議. pp.213 - 218.

5) H. MURAKAMI et al (2005) : The Use of Microporous Siliceous Shale and Zeolite for High-Performance Radiation Shielding Materials, Proc. of ICMR - AKITA.

6) 木村智博, 三橋博巳，青山清道，猪爪高見（2006）: 避難 等の状況, 『2004 年新潟県中越地震被害調査報告書』, 日 本建築学会. pp.184 - 198.

7) 村上正浩 (2006) : 被災者支援とボランティア活動,『2004 年新潟県中越地震被害調查報告書』, 日本建築学会. pp.199 - 203.

8) 木村智博, 三橋博巳, 川原潮子, 猪爪高見, 青山清道, 福田誠, 坂井優美, 酒井由美（2006）: アンケート調査に よる 2004 新潟県中越地震後の寒冷下での健康問題, 建築 学会技術報告集. 第 24 号. pp.451 - 456.

9) 福田誠, 新関敦生, 木村智博, 青山清道, 山本仁志ほか （2007）：雪崩予防柵の被害，『地盤工学会 2004 年新潟県 中越地震災害調査委員会報告書』, DVD-ROM 版は pp.490 - 528. 冊子版 pp.485 - 518 .

10) 福田誠, 木村智博, 岡田勝也, 田口洋治 (2008) : 新潟県 での災害廃棄物処理の現状と課題一地震後の環境対策を 考える一，土木学会誌. Vol.93. No.10. pp.34-37.

11）嘉門雅史，乾徹（2002）: 管理型廃棄物処分場の地盤工学 的問題と対策，土木学会論文集. No.701 / III-58. pp.1 15.

12）日本応用地質学会 災害廃棄物の防災と環境に関する研 究小委員会 編 (2007) : 2007 年新潟県中越沖地震におけ る災害廃棄物の現地調査報告，全12 頁. 2007.12.7.

13) K. AOYAMA, K. KATOH, T. MURANO, T. PACES and T. TAGUCHI et al (1997) : Proc. of International Conference of Acid Snow and Rain, TACT.

14）日本集団災害医学会を筆頭に，日本救急医学会，日本公 衆衛生学会, 日本旅行医学会, 宮野道雄 大阪市立大学生 活科学部教授らが関係する日本生理人類学会等の年次大 会や学術誌で避難生活に係るアンケート調査結果が掲載 され，市販ではへるす出版発行の月刊誌「救急医学」，プ
ライマリケア医が購読する南山堂の月刊誌「治療」，コメ ディカルを含む幅広い読者層に支持される医歯薬出版の 「週刊医学のあゆみ」において随時, 災害医療特集が組 まれている.

15) 高尾堅司（2006）：災害廃棄物の実態調査一新潟県三条 市・福井県福井市・兵庫県豊岡市を事例として一，防災 科学技術研究所主要災害調査. 第 40 号. pp.129 - 134.

16) 藤原輝夫 (1995) : 神戸市の災害廃棄物対策, 廃棄物学会 誌. Vol.6. No.5. pp.380 - 393.

17) 東京都環境局，東京都総務局 編（2007）: 新潟中越沖地 震に伴う東京都の支援について一特別区による廃棄物処 理の支援について—（第 20 報）， http://www.metro.tokyo.jp/INET/OSHIRASE/2007/08/20h8o2 00.htm に掲載.

18）八村智明，宮原哲也，大野博之（2007）：災害廃棄物によ る地下水・土壌污染の可能性，応用地質. Vol.47. No.6. pp.360 - 368.

19) 福田誠, 木村智博 (2008) : 海岸漂着ゴミの地盤工学的対 策, 地盤工学会誌. Vol.56. No.8. pp.32 - 33 .

20) 福田誠, 木村智博 (2009) : 震㷋廃棄物,『地盤工学会 2007 年新潟県中越沖地震災害調査委員会報告書』，全9頁.

21）小島圭二, 田村昌三, 島田荘平, 石井英二, 田中 勝, 登 坂博行，中杉修身，山川 稔 編（2000）: 『廃棄物処分・ 環境安全用語辞典』, 丸善. pp.329 - 330 .

22) 中島募（2007）: 土壌污染浄化の最新技術一水蒸気の力で 污染を浄化一, 日経ビジネス. 2007.9.17 号. pp.112 - 114.

23）神﨑広史, 立木英機（2004）: 情報提供を伴う働き掛けが 家庭ごみの排出に及ぼす影響について，廃棄物学会論文 誌. Vol.15. No.2. pp.77 - 85.

\section{謝辞}

本研究でヒアリング等の協力を賜つた柏崎市市民生活 部クリーン推進課, 刈羽村住民福祉課, 新潟県県民生活・ 環境部廃棄物対策課, 長岡市環境部環境施設課, 中越環 境開発（株）や各施設の担当者に厚くお礼を申し上げる とともに，アンケートに回答された方を含む被災された 方達の一日も早い復興を祈念致します. 最後に, 本研究 に際するアンケート集計や各種資料整理，画像トリミン グ処理等でお世話になった JR グループに所属する西塚 雅幸 氏（研究当時は国土舘大学理工学部学部生）に, こ の場を借りて謝意を表するものと致します。 


\title{
EVALUATION OF DISPOSED DISASTER WASTE IN CASE OF THE NIIGATAKEN CHUETSU-OKI EARTHQUAKE IN 2007
}

\author{
Yumi SAKAI ${ }^{1}$, Tomohiro KIMURA ${ }^{2}$, Makoto FUKUDA ${ }^{3}$, Osamu HASHIMOTO ${ }^{4}$, \\ Katsuya OKADA ${ }^{5}$, Mari ITOH $^{6}$, Chouko KAWAHARA $^{7}$, and Motoi IWANAMI ${ }^{8}$ \\ ${ }^{1}$ Former Undergraduate Student, Niigata University \\ ${ }^{2}$ Dr. of Environmental Studies, Former Graduate Student, University of Tokyo (E-mail:mucunzhibo@yahoo.co.jp) \\ ${ }^{3}$ Dr. of Engineering, Emeritus Prof., Nagaoka National College of Technology (E-mail: fukudam@clock.ocn.ne.jp) \\ ${ }^{4}$ Chief Director, Tokyo Metropolitan Government \\ ${ }^{5}$ Dr. of Engineering, Prof., Kokushikan University \\ ${ }^{6}$ Reporter, The Asahi Shimbun \\ ${ }^{7}$ Reporter, The Asahi Shimbun \\ ${ }^{8}$ Dr. of Engineering, Associate Prof., Nagaoka National College of Technology \\ (E-mail: miwanami@nagaoka-ct.ac.jp)
}

\begin{abstract}
Conducted study on disposed disaster wastes were scrutinized and achieved by The Japan Society of Waste Management Experts mainly, and geotechnical aspect of Japan Society of Engineering Geology or The Clay Science Society of Japan after 1995 South Hyogo Prefecture Earthquake from the environmental impacts as bloated garbage. In this paper, the authors indicated desirable risk management, as determined by the regional features considering with waste management in case of The Niigataken Chuetsu-oki Earthquake in 2007 based on reconnaissance investigation and questionnaire. Furthermore, we analyzed recyclable geotechnical material with our experiment, as reference to Tokyo Metropolitan Government. Sequential surveys resulted in reduction of waste amount due to the separated garbage collection system by residents in persistent, ultimately, ban for enormity dumping under cooperation between family or citizen, therefore environmental mitigation as to vulnerability from helm of wallow mixtured waste through field survey and enquête. In addtion to that, we mentioned heavy metals in huge wastes based on our monitoring results of coastal area in Niigata Prefecture, and overviewed geotechnical remedy.
\end{abstract}

Key Words: The Niigataken Chuetsu-oki Earthquake in 2007, Disposed Disaster Waste, Questionnaire Survey, Environmental Impact Assessment, Waste Management 